\title{
BIOLOGY
}

\section{Carbon primary sources and estuarine habitat use by two congeneric ariid catfishes in a subtropical coastal lagoon}

\author{
Paula E.R. Pereyra ${ }^{1}{ }^{\star}$, Renata Mont'Alverne $^{1} \&$ Alexandre M. Garcia $^{1}$
}

\author{
${ }^{1}$ Instituto de Oceanografia, Universidade Federal do Rio Grande. Avenida Itália km 8, Carreiros, 96203-900 Rio \\ Grande, RS, Brazil. \\ *Corresponding author. E-mail: paulinharubira@hotmail.com
}

\begin{abstract}
Although ariid catfishe species are known to use coastal systems during some stages of their life cycles, the energetic contribution of estuarine resources and habitat use by many species in this family are still unclear. We used stable isotope analyses to estimate the assimilation of primary carbon sources and to infer the use of estuarine and freshwater habitats by two ariid catfishes Genidens barbus (Lacepède, 1803) and Genidens genidens (Cuvier, 1829). An isotopic mixing model revealed that juveniles of both catfish species consume considerable amounts of estuarine-produced carbon sources (G. barbus: $54-87 \%$ and G. genidens: $36-84 \%)$. However, G. genidens adults rely more on freshwater-derived carbon sources (31-77\%) than on estuarine sources (23-69\%). These results support the hypothesis that both species occupy the estuary and assimilate organic carbon produced in this region during their early stages, but $G$. genidens adults consume carbon sources associated with the freshwater portion of the lagoon.
\end{abstract}

KEY WORDS. Genidens barbus, Genidens genidens, isotopic mixing models, Patos Lagoon, stable isotopes.

Estuaries are biologically much more productive than their adjacent rivers and the sea. The hydrodynamic characteristics of estuaries favor nutrient retention and high levels of primary production (DAY et al. 1989, MiRANDA et al. 2002). In some cases, estuarine production is exported to the adjacent marine area, where it is assimilated by coastal organisms (SAVAGE et al. 2012). Fish moving in and out of estuaries into adjacent areas can mediate this nutrient flux between ecosystems (NeLSON et al. 2012, JARDINE et al. 2012), generating carbon subsidies among food webs of marine, estuarine and freshwater regions (McAvor et al. 2000, Garcia et al. 2007, Koshino et al. 2013). Examples of fish using estuaries during part of their life cycle (e.g., as juveniles) and then moving into adjacent marine or freshwater areas are commonly found among catfishes (CHAO et al. 1985, Araújo 1988, Gomes \& Araújo 2004, Rocha et al. 2012). At Patos Lagoon $\left(32^{\circ} \mathrm{S}\right)$, for instance, young-of-the-year Genidens barbus (Lacepède, 1803) born in summer move from the northern limit of the estuarine zone (close to the freshwater portion of the lagoon) to the southern reaches of the estuary (near its connection with the sea) in autumn and winter, and return back to the freshwater region in the following spring and summer. Juveniles repeat this movement between fresh and brackish waters, and when they become sub-adults (older than two years) they join the adult population and migrate to the sea, where they remain until it is time to come back to spawn in the upper freshwater reaches of the lagoon (ARAÚJo 1988). The proportion of estuarine and freshwater-derived food sources in the diet of many catfish species during different phases of their life cycle is still unclear. For instance, prior studies based on the distribution and abundance of the Ariidae catfish species Genidens genidens (Cuvier, 1829) and G. barbus, which are commonly found in southwestern Atlantic estuaries (BARletTA \& Blaber 2007, JALAL et al. 2012), described contrasting life cycle models for these species. Earlier work conducted in the 1980's at Patos Lagoon documented that the catfish G. genidens is an estuarine resident (i.e., completes its entire life cycle within the estuary) and the marine catfish G. barbus is an anadromous species (i.e., adults migrate from marine areas to breed in the freshwater reaches of this lagoon) (ChAO et al. 1985, Reis 1986, Araújo 1988). Previous studies in other estuaries of the Atlantic Southwest (Mazzon et al. 2000, Denadar et al. 2012, Rocha et al. 2012) have also claimed that ariid catfishes use the estuarine zone for reproduction, development and/or for feeding. However, we do not know of any prior studies using natural tracers to investigate how ariid catfish species use estuarine and freshwater habitats in southwestern Atlantic estuaries.

Stable isotope analysis has been widely employed to investigate movement patterns and habitat use by aquatic animals 
(Rubenstein \& Hobson 2004, Guelinckx et al. 2008, Vinagre et al. 2011). It investigates the differences in the isotopic composition at the base of the food web in different habitats (e.g., oceanic vs. coastal; estuary vs. freshwater) and can be used to track animal movement between habitats (Fry 2006). For example, GARCIA et al. (2007) showed that the isotopic composition of fish found in the estuarine and freshwater regions of Patos Lagoon differ from each other (average $\delta^{13} \mathrm{C}$ : $-17 \%$ SD: 2.75 and $-21 \%$ SD: 1.97 , respectively) because they reflect differences in the average isotope values of primary producers of each location (average $\delta^{13} \mathrm{C}$ : $-21 \%$ o SD: 7.29 and $-28 \%$ o SD: 1.32, respectively).

In this work we investigate the isotopic differences of two congeneric species of catfish ( $G$. genidens and G. barbus) that have contrasting life cycles, and which move between the estuarine and freshwater habitats of the Patos Lagoon, which have distinct isotopic baselines. We use these tracers to infer their assimilation of primary carbon sources. Our hypothesis was that the estuarine environment provides basic food sources for both species during the initial phase of their life cycles.

\section{MATERIAL AND METHODS}

Patos Lagoon is one of the largest subtropical coastal lagoons in the world (Kjerfve 1986, Möller \& Fernandes 2010). It is connected to the South Atlantic Ocean by a single inlet located between two $\sim 5 \mathrm{~km}$-long rocky jetties and $18 \mathrm{~m}$ deep. The precipitation, river discharge, salinity and wind patterns are the main physical driving forces controlling the hydrological conditions of the estuarine zone of Patos Lagoon (CostA et al. 1988).

Fish and other food web components were sampled from the research vessel Larus of the Universidade Federal do Rio Grande (FURG) in September 2011. Samples of fish populations were obtained in three sampling stations located in a salinity transition region of Patos Lagoon between the upper limit of the estuary and its freshwater zone (Fig. 1). The basal food sources were collected at 8 locations along the longitudinal axis of Patos Lagoon, distributed between its estuarine and lower freshwater reaches (Fig. 1). The basal food sources sampled included representative species of marsh plants, seagrass and macroalgae, and also suspended particulate organic matter (SPOM) and particulate organic matter in the sediment (SOM). Samples of the primary producers were collected by hand using scissors. SPOM was obtained through filtration of approximately 0.25 to 1.00 liter of water collected at each sampling location into glass-fiber filters $(0.75 \mu \mathrm{m})$. In order to obtain a sample of SOM, we removed about $2 \mathrm{~cm}$ of sediment surface using a plastic core (10 cm diameter) in shallower water sites $(<1.5 \mathrm{~m})$ and a Van Veen grab in deeper sites ( $>2 \mathrm{~m}$ ).

Catfishes ( $G$. barbus and G. genidens) were caught using a $9 \mathrm{~m}$ wide (mouth) and $7 \mathrm{~m}$ long bottom trawl net with a 15 $\mathrm{mm}$ mesh in the wings, $12 \mathrm{~mm}$ in the central portion and 6 $\mathrm{mm}$ in the bag. Each haul lasted five minutes. We collected both juveniles $(\mathrm{N}=9)$ and adults of $G$. genidens $(\mathrm{N}=9)$, but
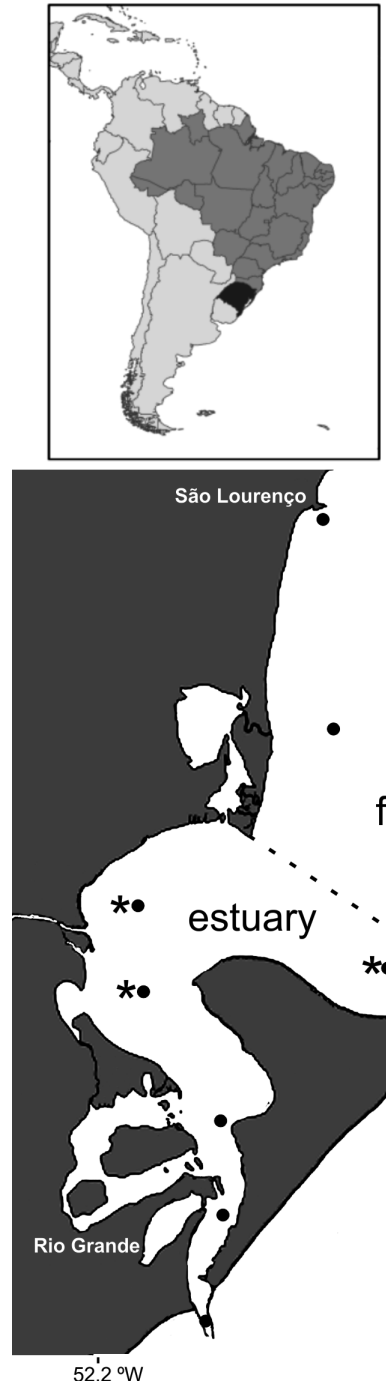

Patos Lagoon

Figure 1. Map showing the sites in the estuarine and freshwater zones of Patos Lagoon, southern Brazil. Asterisks denote the locations where individuals of Genidens genidens and Genidens barbus were collected; closed circles denote the locations where marsh plants, seagrass, macroalgae and suspended particulate organic matter (SPOM) and sediment (SOM) samples were collected.

only juveniles of $G$. barbus $(\mathrm{N}=22)$. We did not collect adults of this species because we did not sample the adjacent marine area, where adults migrate to reproduce. Based on prior work (Rocha \& Freire 2009), we considered as juveniles and adults of G. genidens the individuals with total length (TL) smaller and larger than $200 \mathrm{~mm}$, respectively. All specimens of G. barbus measured less than 415 TL mm and were considered juveniles (REIs 1986). Adults are approximately three-folds larger than $G$. genidens. All samples were stored on sealed plastic bags and stored on ice until transferred to the laboratory, where they were kept 
in a freezer until they were processed (JARDINE et al. 2003, GARCIA et al. 2007, Hoeinghaus et al. 2011).

After thawing, primary producers and fish were cleaned with distilled water (to remove any material adhered to the tissue of interest), placed on a sterile Petri dish and dried in an oven at $60^{\circ} \mathrm{C}$ to constant weight (minimum of 48 hours). We processed and analyzed leaves of marsh plants and seagrass, and filaments of macroalgae. The tissue of choice to analyze fish samples was the anterior-dorsal muscle. Dried samples were ground to a fine powder with a mortar and pestle and stored in clean Eppendorf tubes. Subsamples were weighed (1-3 mg for animal tissues, 25-30 mg for SOM and approximately $3 \mathrm{mg}$ for other basal sources), pressed into Ultra-Pure tin capsules (Costech Analytical, Valencia, California), and sent to the Analytical Chemistry Laboratory of the Institute of Ecology, University of Georgia, for analysis of carbon isotope ratios. Results are expressed in delta notation (parts per thousand deviation from a standard material $): \delta^{13} \mathrm{C}=\left[\left(R_{\text {sample }} / R_{\text {standard }}\right)-1\right]$ * 1000 , where $R={ }^{13} \mathrm{C} /{ }^{12} \mathrm{C}$. The standard material for carbon is Pee Dee Belemnite (PDB) limestone.

Analysis of variance (ANOVA) was used to test statistical differences in $\delta^{13} \mathrm{C}$ mean values between the two catfish species, and the student t-test was used to evaluate differences in $\delta^{13} \mathrm{C}$ values between juvenile and adult individuals of G. genidens. A biplot of $\delta^{13} \mathrm{C}$ and average total length (TL, $\mathrm{mm}$ ) of each individual was employed to distinguish patterns in isotopic composition between both catfish species and their correlation was evaluated using a linear regression. In order to infer habitat use for each species, intraspecific variations in carbon isotope ratios were compared to carbon isotopic baselines representative of the estuarine and lower freshwater reaches of the Patos lagoon. As isotope baseline we considered representative species of marsh plants, seagrass and macroalgae, SOM and SPOM collected at the estuarine and freshwater reaches of the lagoon in this study $(n=62)$. SOM and SPOM consist of pools of microalgae, organic matter and detritus of pelagic and benthic origin (DAY et al. 1989), which, in case of the SOM, can reflect the dominant local vegetation (KeNNEDy et al. 2010). We used the SIAR (Stable Isotope Analysis in R) Bayesian approach for isotopic mixtures (PARNELL et al. 2010) to estimate the relative association of each catfish species with the estuarine and freshwater isotopic baselines. The variability in isotopic composition of basal food sources was incorporated into the mixing models as standard deviations of carbon isotope ratios of each basal food source at the estuarine and freshwater zones. A key parameter used in isotopic mixing models is the trophic enrichment factor (TEF) that is the isotopic difference between the tissues of consumers and the tissues of their food sources after they reached equilibrium (Fry 2006, PARnell et al. 2010). In most cases, these differences arose from preferential accumulation of heavier isotopes (e.g., ${ }^{13} \mathrm{C}$ in detriment of ${ }^{12} \mathrm{C}$ ) in animal tissues when compared to their food (Martinez Del Rio et al. 2009). In the absence of species-specific TEF values obtained in controlled diet experiments, it is usual to employ TEF values obtained in meta-analyses for species phylogenetically or trophically related (Pоsт 2002, Newsome et al. 2007). We used a TEF of 0.47 with a standard deviation of 1.23 per trophic level, which was obtained in the meta-analysis carried out by VANDER ZANDEN \& RASMUSSEN (2001). We considered two trophic levels for both species in our mixing models, therefore, we multiplied our TEF value by 2 .

In order to evaluate the potential influence of interanual isotopic variability in the basal food sources comprising our isotope baseline, we also modeled fish assimilation of estuarine and freshwater-derived food sources considering an extensive dataset ( $\mathrm{n}=95$ samples) of $\delta^{13} \mathrm{C}$ values of marsh plants, seagrass and macroalgae, SOM and SPOM collected at the estuarine and freshwater reaches of the lagoon in this study $(n=62)$, by GARCIA et al. (2007) $(\mathrm{n}=13)$ in November 2004 and also by Claudino et al. (2013) $(n=20)$ in September 2010 (Table 1).

\section{RESULTS}

The mean values and standard deviations of the primary producers, SPOM and SOM, used to build the isotopic baseline, are shown in Table 1 . A total of 95 samples were collected, 48 at freshwater sites in the northern reaches of the lagoon $(\mathrm{SPOM}=6, \mathrm{SOM}=11$, Marsh plants $=4$, Macrophytes $=15$, Floating macrophytes $=12$ ) and 47 at the estuarine region of the lagoon $(\mathrm{SPOM}=6, \mathrm{SOM}=14$, Marsh plants $=15$, Macroalgae = 8 , Seagrass $=4)$. Total average values and standard deviations of carbon isotope ratios $\left(\delta^{13} \mathrm{C}\right)$ of basal food sources at freshwater and estuary regions were -26.93 (2.55) and -20.17 (7.86), respectively (Table 1 ).

In general, comparisons between the average values of carbon isotopic ratios $\left(\delta^{13} \mathrm{C}\right)$ revealed significant differences between the two catfish species, with lower $\delta^{13} \mathrm{C}$ values for $G$. genidens $(-19.23 \%$ \pm 1.41$)$ when compared to G. barbus $(-17.18 \% \pm 0.78)$ $(\mathrm{F}(1,37)=32.7504, \mathrm{p}<0.00)$. The comparison between juvenile and adult individuals of $G$. genidens also revealed significant differences in carbon isotope ratios (t-test $=2.699, \mathrm{p}<0.016$ ), with juveniles showing enriched average $\delta^{13} \mathrm{C}(-18.45 \%$ t 1.50$)$ compared to adults $(-19.99 \%$ \pm 0.81$)$. Intraspecific variations in $\delta^{13} \mathrm{C}$ values in relation to individual body size revealed contrasting patterns (Fig. 2). Genidens barbus individuals showed lower variation in $\delta^{13} \mathrm{C}$ values $(-19.05 \%$ to $-16.03 \%$ ) and no correlation with body size $(\mathrm{r}=-0.329, \mathrm{p}>0.145)$. In contrast, $G$. genidens had a much larger variation in $\delta^{13} \mathrm{C}$ values $(-21.25 \%$ to $-16.20 \%$ ) and a marked negative correlation with body sizes $(\mathrm{r}=-0.843, \mathrm{p}<0.000)$ (Fig. 2).

The SIAR mixing models revealed that most of the carbon content in juvenile G. barbus was derived from the estuarine region (95\% credibility interval - CI $=54-87 \%$ ) when compared with the freshwater region $(95 \% \mathrm{CI}=13-46 \%)$. Juveniles of $G$. genidens also derived most of their carbon from the estuary $(95 \%$ $\mathrm{CI}=36-84 \%)$ when compared with freshwater basal source $(95 \%$ $\mathrm{CI}=16-64 \%)$. However, upon reaching the adult stage, their 
Table 1. Means and standard deviations (SD) of carbon isotope ratios $\left(\delta^{13} \mathrm{C}\right.$ of primary producers, SPOM and SOM used to build the isotopic baseline of freshwater and estuarine reaches of Patos Lagoon. Data source: (1) This study, (2) GARCIA et al. 2007, (3) Claudino et al. 2013.

\begin{tabular}{|c|c|c|c|c|}
\hline Species & $\mathrm{N}$ & Mean & SD & Data source \\
\hline \multicolumn{5}{|l|}{ Freshwater } \\
\hline \multicolumn{5}{|l|}{ Marsh plants } \\
\hline Schoenoplectus californicus & 4 & -25.90 & 0.31 & $1-2$ \\
\hline \multicolumn{5}{|l|}{ Macrophytes } \\
\hline Bacopa spp. & 6 & -26.14 & 0.79 & 1 \\
\hline Echinodorus spp. & 1 & -26.96 & & 2 \\
\hline Enydra spp. & 1 & -30.44 & & 2 \\
\hline Ludwigia peploides & 3 & -27.79 & 0.64 & 1 \\
\hline Polygonum spp. & 1 & -28.95 & & 2 \\
\hline Pontederia subovata & 3 & -24.38 & 0.30 & 1 \\
\hline \multicolumn{5}{|l|}{ Floating macrophytes } \\
\hline Eichhornia azurea & 4 & -27.63 & 0.69 & $1-2$ \\
\hline Eichhornia crassipes & 1 & -27.96 & & 2 \\
\hline Eichhornia spp. & 3 & -28.46 & 0.32 & 1 \\
\hline Pistia stratiotes & 1 & -27.82 & & 2 \\
\hline Salvinia diminuta & 2 & -29.89 & 0.75 & 1 \\
\hline Salvinia spp. & 1 & -27.80 & & 2 \\
\hline SPOM & 6 & -22.83 & 0.72 & 1 \\
\hline SOM & 11 & -21.03 & 1.65 & 1 \\
\hline Total & 48 & -26.93 & & \\
\hline SD & & 2.55 & & \\
\hline
\end{tabular}

\begin{tabular}{lcccc}
\hline Estuary & & & & \\
Marsh plants & 1 & -27.52 & & 2 \\
$\quad$ Cladium jamaicensis & 1 & -27.97 & & 2 \\
$\quad$ Cyperus giganteus & 2 & -27.95 & 0.52 & 3 \\
$\quad$ Juncus acutus & 1 & -26.33 & & 2 \\
$\quad$ Juncus effusus & 5 & -27.00 & 0.42 & $2-3$ \\
$\quad$ Scirpus maritimus & 5 & -12.15 & 0.43 & $2-3$ \\
$\quad$ Spartina densiflora & & & & \\
Macroalgae & 2 & -10.11 & 0.21 & 3 \\
$\quad$ Rhizoclonium spp. & 6 & -10.28 & 0.73 & 1 \\
$\quad$ Ulva spp. & & & & \\
Seagrass & 4 & -10.94 & 0.85 & 3 \\
$\quad$ Ruppia maritima & 6 & -22.81 & 2.12 & 1 \\
\hline SPOM & 14 & -18.81 & 2.32 & $1-3$ \\
SOM & 47 & -20.17 & & \\
Total mean & & 7.86 & & \\
SD & & & & \\
& & & & \\
\end{tabular}

isotopic signatures tended to reflect consumption of freshwater food sources $(95 \% \mathrm{CI}=31-77 \%)$ and comparatively less from estuarine food ones (95\% CI =23-69\%) (Fig. 3). These findings remained similar when mixing models were run with a more extensive isotope baseline ( $\mathrm{n}=95$ samples) including interanual variability in basal food sources at estuarine and freshwater zones of the lagoon (Fig. 4).

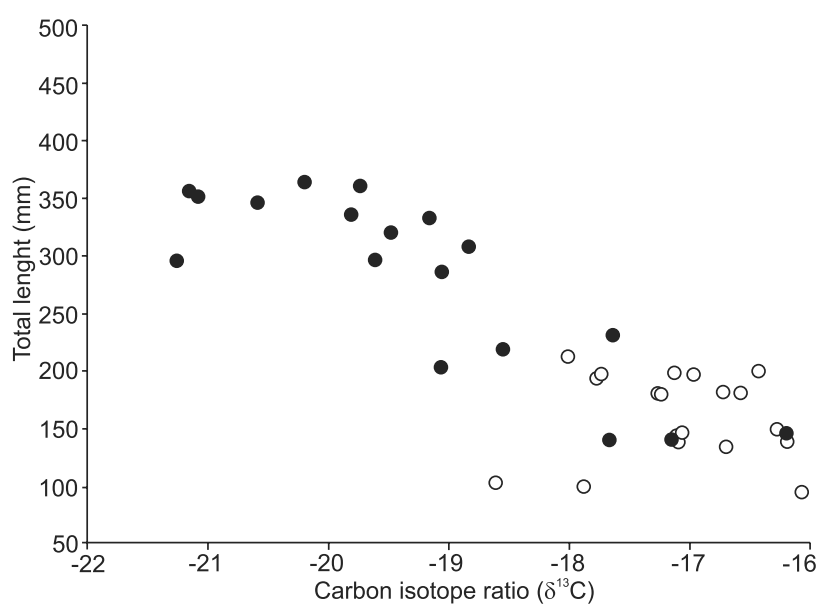

Figure 2. Carbon isotope ratios $\left(\delta^{13} \mathrm{C}\right)$ and total length $(\mathrm{TL}, \mathrm{mm})$ of individuals of Genidens genidens (closed circles) and Genidens barbus (open circles) collected in the interface between the estuarine and freshwater zones of Patos Lagoon in present study.

\section{DISCUSSION}

According to the model of the life cycle suggested by ARAÚjo (1988), G. barbus move between freshwater to the estuary during their first year of life. After reaching sexual maturity, adults migrate to the ocean, returning to freshwater to spawn. Our work with stable isotopes corroborates the general movement pattern proposed in this model by providing evidence that the primary producers at the estuary are an important source of carbon for juveniles of G. barbus during the initial phase of their development. There is no current model describing the life cycle of G. genidens at the Patos Lagoon. AraúJo (1988) mentioned that this species remains in the upper limit of the estuarine zone or in the limnetic portion of the lagoon and that its juveniles are occasionally found in the estuary. Based on fish sampling restricted to the mixohaline zone of the Patos Lagoon, some authors classified this species as estuarine resident (CHAO et al. 1985, AraúJo 1988). However, VieIRA et al. (2010) demonstrated that $G$. genidens occurs from the estuary to the uppermost northern portion of the lagoon, which is located $\sim 180 \mathrm{~km}$ from the lagoon's connection with the sea, and can remain year round at freshwater. Our work provides new evidence that this catfish species derives energy from the estuarine and freshwater zones of this lagoon in different phases of its development. Intraspecific trends in carbon isotope ratios suggest that juveniles depend mostly on estuarine-derived carbon sources, but when they become adults, they shift to carbon sources associated with the freshwater reaches of the lagoon. This carbon shift probably occurs as a function of isotopic differences between freshwater and estuarine habitats of the Patos lagoon (GARCIA et al. 2007). At its estuarine zone, ${ }^{13} \mathrm{C}$-enriched plants with $\mathrm{C}_{4}$-photsyntetic pathway are commonly found (e.g., Spartina densiflora, S. alterni- 
G. barbus (juveniles)

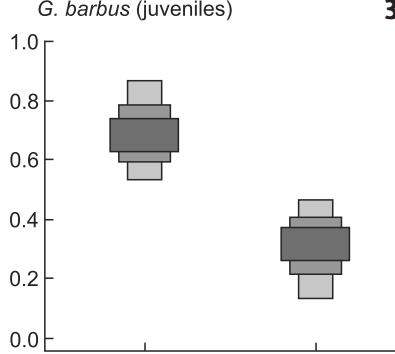

G. genidens (juveniles)

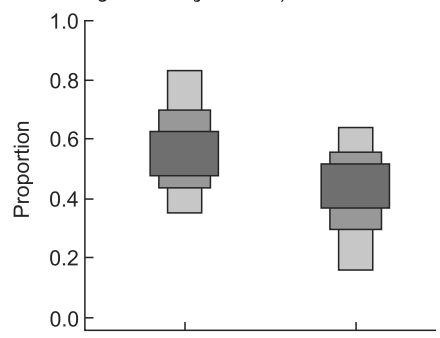

G. genidens (adults)

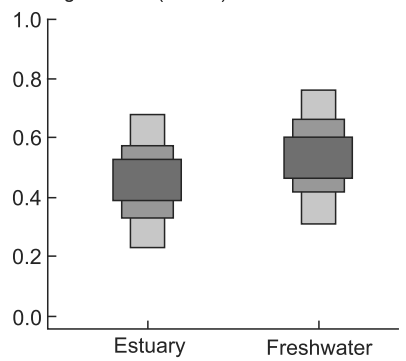

3
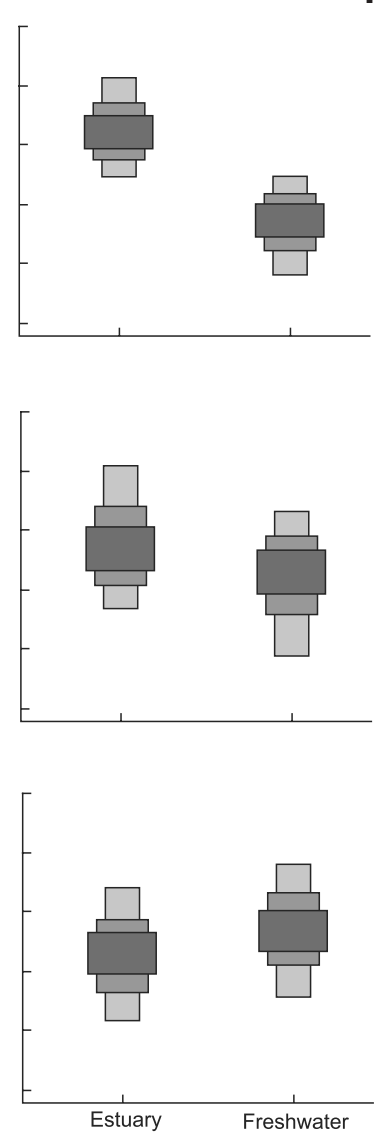

Figures 3-4. Relative contribution of estuarine and freshwater basal sources to Genidens barbus and G. genidens estimated by the mixing model SIAR and their respective credibility intervals of $95 \%$ (light gray), $75 \%$ (intermediate gray) and 50\% (dark gray). (3) Results obtained with the static isotope baseline $(n=62$ samples collected at September 2011). (4) Results obtained with the isotopic baseline ( $n=$ 95 samples), encompassing interanual variability in basal food sources.

flora, Ruppia maritima), but they are absent in the freshwater reaches of the lagoon, where ${ }^{13} \mathrm{C}$-depleted $\mathrm{C}_{3}$ plants dominate (e.g., Salvinia sp., Eichhornia azurea, Pistia striolates, Eichhornia crassipes, Scirpus californicus) (GARCIA et al. 2007).

The trophic importance of estuarine resources for Ariid catfishes has been proposed earlier based on stomach contents analysis (Araújo 1984, Chaves \& Vendel 1996, Mendoza-Carranza \& Vieira 2009, Denadar et al. 2012). For example, trophic ecological studies on G. genidens and G. barbus in southwestern Atlantic estuaries highlighted the importance of estuarine invertebrates in their diet (Araújo 1984, Mendoza-Carranza \& Vieira 2009), for instance polychaets, mollusks, zooplankton and, especially, the tanaid Kalliapseudes schubartii Mañé-Garzón, 1949, which can reach high densities $\left(\sim 12.808\right.$ ind. $\left.\mathrm{m}^{2}\right)$ in estuarine mudflats (Bemvenuti 1987, Rosa-Filho \& Bemvenuti 1998). Our stable iso- topes revealed a habitat-related shift in primary carbon sources sustaining G. genidens. Juveniles of this species rely mainly on estuarine resources. Later on, when they become adults and move to the freshwater reaches of the lagoon, they switch to freshwater-derived resources. Future studies combining stable isotopes and stomach content analyses need to be carried out to unravel changes that might occur in the diet and trophic links of the preys of $G$. genidens when it moves from estuarine to freshwater.

Finally, it is worth noting that the basic assumption behind stable isotope mixing models (i.e., consumers reflect the isotopic composition of their food sources) is dependent of the complex dynamics of food-consumer isotope discrimination factor and tissue-specific turnover rates of carbon and nitrogen (FrY 2006). Unfortunately, these parameters have not been estimated for many ecosystems, food webs, species and tissues that have been subjected to stable isotope analyses (GANNEs et al. 1997, Martinez Del Rio et al. 2009) and our studied lagoon and species are not exceptions. We attempted to minimize this problem by also evaluating our results against an isotopic baseline comprised of a larger dataset ( $\mathrm{n}=95$ samples) covering potential isotopic variation occurring across several seasons and years. A prior analysis in this estuary revealed that monthly variation in carbon isotope ratios of the most representative marsh plants of the Patos Lagoon estuary are less than three per mil during the year (Claudino et al. 2013). Apparently, our extensive isotope baseline integrating isotope variations in space and throughout different years were robust enough to infer the use of estuarine and freshwater habitats for both catfishes, despite the inherent noise included in these mixing models. Laboratory studies on species-specific trophic discrimination factors and tissue turnover rates (e.g., Mont'Alverne et al. 2016) are needed to allow more accurate interpretation of catfish movement and habitat use in this subtropical lagoon.

In summary, our findings revealed that both G. barbus and G. genidens derived important amounts of estuarine-produced carbon sources in their juvenile stages, and that G. genidens adults relied more on freshwater-derived carbon sources. In order to advance our current understanding of the life cycles and habitat use of these catfish species, we need more studies on the isotopic composition of their food sources, along with an investigation of the salinity gradients (from sea to estuary to freshwater). Laboratory studies on trophic discrimination factors and tissue turnover rates, integrated with other natural tracers as otolith microchemistry, might also be helpful.

\section{ACKNOWLEDGEMENTS}

We are thankful to J. P. Vieira and S. Botta for their comments on an earlier version of the manuscript; to colleagues in the Ichthyology Laboratory at FURG for their assistance in sampling processing. The study was funded by the Ministry of Science and Technology (MCT/CNPq) through the Brazilian 
Long Term Ecological Research Program (BR-LTER) at Site 8: Patos Lagoon estuary. AMG acknowledges a fellowship from Conselho Nacional de Desenvolvimento Científico e Tecnológico (proc. 305888/2012-9).

\section{LITERATURE CITED}

Araújo FG (1984) Hábitos alimentares de três bagres marinhos (Ariidae) no Estuário da Lagoa dos Patos (RS), Brasil. Atlântica 7: 43-67.

ARAújo FG (1988) Distribuição, abundância relativa e movimentos sazonais de bagres marinhos (Siluriformes, Ariidae) no Estuário da Lagoa dos Patos (RS), Brasil. Revista Brasileira de Zoologia 5(4): 509-543. doi: 10.1590/S010181751988000400002

Barletta M, Blaber SJM (2007) Comparison of fish assemblages and guilds in tropical habitats of the Embley (Indo-West Pacific and Caeté (Western Atlantic) estuaries. Bulletin of Marine Science 80(3): 647-680.

Bemvenuti CE (1987) Predation effects on a benthic community in estuarine soft sediments. Atlântica 9: 5-32.

Chao LH, Pereira LE, Vieira JP (1985) Estuarine fish community of the dos Patos Lagoon, Brazil: A baseline study, p. 429450. In: YÁñEz-Arancibia A (Ed.) Fish Community Ecology in Estuaries and Coastal Lagoons: Towards an Ecosystem Integration. Mexico, UNAM Press, 654p.

Chaves PTC, Vedel AL (1996) Aspectos da alimentação de Genidens genidens (Valenciennes) (Siluriformes, Ariidae) na baía de Guaratuba, Paraná. Revista Brasileira de Zoologia 13(3): 669-675. doi: 10.1590/S0101-81751996000300016

Claudino MC, Abreu PC, Garcia AM (2013) Stable isotopes reveal temporal and between-habitat changes in trophic pathways in a southwestern Atlantic estuary. Marine Ecology Progress Series 489: 29-42. doi: 10. 3354/meps10400

Costa CSB, Seeliger U, KInAs PG (1988) The effect of wind velocity and direction on the salinity regime in the lower Patos Lagoon estuary. Ciência e Cultura 40(9): 909-912.

Day JW, Hall CAS, Kemp WM, Yáñez-Arancibia A (1989) Estuarine ecology. New York, John Wiley and Sons, 558p.

Denadai MR, Bessa E, Santos FB, Fernandez WS, Santos FMC, Feijó MM, Arcuri ACD, Turra A (2012) Life history of three catfish species (Siluriformes: Ariidae) from southeastern Brazil. Biota Neotropica 12(4): 74-83. doi: 10.1590/S167606032012000400008

FRY B (2006) Stable Isotope Ecology. New York, Springer, 370p. Gannes LZ, O’Brien DM, Martínez Del Rio C (1997) Stable isotopes in animal ecology: assumptions, caveats, and a call for more laboratory experiments. Ecology 78(4): 1271-1276.

Garcia AM, Hoeinghaus DJ, Vieira JP, Winemiller KO (2007) Isotopic variation of fishes in freshwater and estuarine zones of a large subtropical coastal lagoon. Estuarine Coastal and Shelf Science 73: 399-408. doi: 10.1016/j.ecss.2007.02.003 Gomes ID, Araújo FG (2004) Reproductive biology of two marine catfishes (Siluriformes, Ariidae) in the Sepetiba Bay, Brazil. Revista de Biologia Tropical 52(1): 143-156.

Guelinckx J, Maes J, Bram G, Ollevier F (2008) Estuarine recruitment of a marine goby reconstructed with an isotopic clock. Oecologia 157(1): 41-52. doi: 10.1007/s00442-008-1045-7

Hoeinghaus DJ, Vieira JP, Costa CS, Bemvenuti CE, Winemiller KO, GARCIA AM (2011) Estuary hydrogeomorphology affects carbon sources supporting aquatic consumers within and among ecological guilds. Hydrobiologia 673(1): 79-92. doi: 10.1007/s10750-011-0751-Z

Jalal KCA, Ahmad Azfar M, Akbar John B, Kamaruzzaman YB, SHAHBUDIN S (2012) Diversity and community composition of fishes in tropical estuary Pahang Malaysia. Pakistan Journal of Zoology 44(1): 181-187.

Jardine TD, McGeachy SA, Paton CM, Savoie M, Cunjak RA (2003) Stable isotopes in aquatic systems: sample preparation, analysis, and interpretation. Canadian Manuscript Report of Fisheries and Aquatic Sciences (2656): 39p.

Jardine TD, Pusey BJ, Hamilton SK, Pettit NE, Davies PM, Douglas MM, Sinnamon V, Halliday IA, Bunn SE (2012) Fish mediate high food web connectivity in the lower reaches of a tropical floodplain river. Oecologia 168(3): 829-838. doi: 10.1007/ s00442-011-2148-0

Kennedy HJ, Beggins J, Duarte CM, Fourqurean JW, Holmer M, MarbÀ N, Middelburg JJ (2010) Seagrass sediments as a global carbon sink: isotopic constraints. Global Biogeochemical Cycles 24(4): GB4026. doi: 10.1029/2010GB003848

KJERFVE B (1986) Comparative oceanography of coastal lagoons, p. 63-82. In: Wolfe DA (Ed.) Estuarine Variability. New York, Academic Press, 509p.

Koshino Y, Kudo H, Kaeriyama M (2013) Stable isotope evidence indicates the incorporation into Japanese catchments of marine-derived nutrients transported by spawning Pacific Salmon. Freshwater Biology 58(9): 1864-1877. doi: 10.1111/ fwb. 12175

Martínez Del Rio C, Wolf N, Carleton SA, Gannes LZ (2009) Isotopic ecology ten years after a call for more laboratory experiments. Biological Reviews 84(1): 91-111. doi: 10.1111/j.1469-185X.2008.00064.X

Mazzoni R, Petito J, Miranda C (2000) Reproductive biology of Genidens genidens, a catfish from the Maricá Lagoon, RJ. Ciência e Cultura 52(2): 121-126.

McAvoy SE, Macko SA, Mcinnich SP, Garman GC (2000) Marine nutrient contributions of freshwater apex predators. Oecologia 122(4): 568-573. doi: 10.1007/s004420050980

Mendoza-Carranza M, Vieira JP (2009) Ontogenetic niche feeding partitioning in juvenile of white sea catfish Genidens barbus in estuarine environments, southern Brazil. Journal of the Marine Biological Association of the United Kingdom 89(4): 839-848. doi: 10.1017/S0025315408002403

Miranda LB, Castro BM, Kjerfve B (2002) Princípios de oceanografia física de estuários. São Paulo, Editora da Cidade de São Paulo, 424p. 
Möller O, Fernandes E (2010) Hidrologia e Hidrodinâmica, p. 17-27. In: Seeliger U, Odebrecht C (Eds.) O estuário da Lagoa dos Patos: um século de transformações. Rio Grande, Editora FURG, 179p.

Mont'Alverne R, Jardine TD, Pereyra Per, Oliveira MClM, Medeiros RS, Sampaio LA, Tesser MB, Garcia AM (2016) Elemental turnover rates and isotopic discrimination in a euryhaline fish reared under different salinities: Implications for movement studies. Journal of Experimental Marine Biology and Ecology 480: 36-44. doi: 10.1016/j.jembe.2016.03.021

Nelson J, Wilson R, Coleman RF, Koenig C, DeVries D, Gardner C, Chanton J (2012) Flux by fin: fish-mediated carbon and nutrient flux in the northeastern Gulf of Mexico. Marine Biology 159(2): 365-372. doi: 10.1007/s00227-011-1814-4

Newsome SD, Martinez Del Rio C, Bearhop S, Phillips DL (2007) A niche for isotopic ecology. Frontiers in Ecology and the Environment 5(8): 429-436.

Parnell AC, Inger R, Bearhop S, Jackson AL (2010) Source partioning using stable isotopes: coping with too much variation. PlosOne 5(3): e9672. doi: 10.1371/journal.pone.0009672

Post DM (2002) Using stable isotopes to estimate trophic position: models, methods and assumptions. Ecology 83(3): 703-718.

ReIs EG (1986) Reproduction and feeding habits of the marine catfish Netuma barba (Siluriformes, Ariidae) in the estuary of Lagoa dos Patos, Brazil. Atlântica 8: 35-55.

Rocha GRA, Freire KMF (2009) Biology and dominance relationships of the main fish species in the Lake Encantada, Ilhéus, Brazil. Acta Limnologica Brasiliensia 21(3): 309-316.

Rocha MS, Santiago IM, Cortez CS, Trindade PM, Mourão JS (2012) Use of Fishing Resources by Women in the Mamanguape River Estuary, Paraiba state, Brazil. Anais da Academia Brasileira de Ciências 84(4): 1189-1199. doi: 10.1590/S000137652012005000060

Rosa-Filho JS, Bemvenuti CE (1998) Caracterización de las comunidades macrobentónicas de fondos blandos en regiones es- tuarinas de Rio Grande do Sul (Brasil). Thalassas 14(1): 43-56. Rubenstein DR, Hobson KA (2004) From birds to butterflies: animal movement patterns and stable isotopes. Trends in Ecology and Evolution 19(5): 256-263. doi: 10.1016/j. tree.2004.03.017

Savage C, Thrush SF, Lohrer AM, Hewitt JE (2012) Ecosystem Services Transcend Boundaries: Estuaries Provide Resource Subsidies and Influence Functional Diversity in Coastal Benthic Communities. PlosOne 7(8): e42708. doi: 10.1371/ journal.pone.0042708

Vander Zanden MJ, Rasmussen JB (2001) Variation in $\delta^{15} \mathrm{~N}$ and $\delta^{13} \mathrm{C}$ trophic fractionation: Implications for aquatic food web studies. Limnology and Oceanography 46(8): 2061-2066. doi: 10.4319/lo.2001.46.8.2061

Vieira JP, Garcia AM, Moraes L (2010) A assembléia de peixes, p. 79-88. In: Seeliger U, Odebrecht C (Eds.) O estuário da Lagoa dos Patos: um século de transformações. Rio Grande, Editora FURG, 179p.

Vinagre C, Salgado J, Cabral HN, Costa MJ (2011) Food web structure and habitat connectivity in fish estuarine nurseries-Impact of river flow. Estuaries and Coasts 34(4): 663-674. doi: 10.1007/s12237-010-9315-0

Submitted: 12 June 2015

Received in revised form: 11 December 2015

Accepted: 23 January 2016

Editorial responsibility: Cassiano Monteiro Neto

Author Contributions: PERP RM AMG: sampling design and data collection; PERP RM: samples processing, PERP RM AMG: data analyzes, PERP RM AMG: writing the paper.

Competing Interests: The authors have declared that no competing interests exist. 